\title{
Can biochar provide ammonium and nitrate to poor soils?. Soil column incubation
}

\author{
Ting Cao, Jun Meng, Hao Liang, Xu Yang, Wenfu Chen*
}

Liaoning Biochar Engineering \& Technology Research Center, Shenyang Agricultural University, Dongling Street, Shenhe District, Shenyang, China. *Corresponding author: syct@syau.edu.cn

\begin{abstract}
Understanding how nitrogen concentrations respond to biochar amendment in different types of soils is important for agricultural management. Here, we analyzed the effects of amendment with rice hull biochar on sandy soil, red soil, and alkaline soil (coastal solonchak) over 13 months, focusing on factors such as ammonium $\left(\mathrm{NH}_{4}^{+}-\mathrm{N}\right)$ and nitrate $\left(\mathrm{NO}_{3}{ }^{-}-\mathrm{N}\right)$ cumulative leachate losses, $\mathrm{pH}$, cumulative volumes of leachates, $\mathrm{NH}_{4}^{+}-\mathrm{N}$ and $\mathrm{NO}_{3}^{-}-\mathrm{N}$ abundance of soils, soil dehydrogenase, and nitrogen-related soil enzyme activities. Our results indicated that biochar amendment increased the $\mathrm{pH}$ of red soil but decreased the $\mathrm{pH}$ of both sandy and coastal solonchak soils; promoted the retention of $\mathrm{NH}_{4}{ }^{+} \mathrm{N}$ in red and sandy soils, but not in coastal solonchak; and reduced the loss of $\mathrm{NO}_{3}^{-}-\mathrm{N}$ during the early stages of leaching but accelerated losses during subsequent leaching stages. Soil nitrogen supply capacity $\left(\mathrm{NH}_{4}{ }^{+}-\mathrm{N}+\mathrm{NO}_{3}{ }^{-}-\mathrm{N}\right)$ greatly increased over the short term, with significant differences between treatments. Further, biochar enhanced concentrations of $\mathrm{NH}_{4}{ }^{+}-\mathrm{N}$ and $\mathrm{NO}_{3}{ }^{-} \mathrm{N}^{-}$in soils, and the addition of biochar stimulated the enzymatic and microbial activities in soil, which may increase the abundance of $\mathrm{NH}_{4}^{+}-\mathrm{N}$ and $\mathrm{NO}_{3}^{-}-\mathrm{N}$. Finally, we found that the response of $\mathrm{NH}_{4}^{+}-\mathrm{N}$ and $\mathrm{NO}_{3}^{-}-\mathrm{N}$ to biochar addition varied among the different soil types.
\end{abstract}

Keywords: Biochar, leaching, ammonium, nitrate, soil

\section{Introduction}

Generally defined as a plant-derived biomass produced by pyrolysis at low temperatures $\left(<700{ }^{\circ} \mathrm{C}\right)$ under conditions of limited oxygen (Freddo et al., 2012), biochar is a porous material with a high surface area and thus has a high sorption capacity, which enhances soil cation exchange capacity (CEC; Laird et al., 2010). Biochar is typically used as a soil enhancement to improve soil physicochemical and $\mathrm{pH}$ properties (Abujabhah et al., 2015; Wang et al., 2015; Shen et al., 2016 ), but its application 
may affect soil micro-ecology and the activities of microbial flora, thereby altering soil nitrogen $(\mathrm{N})$ fixation and nitri fication or enzymatic activities (Awasthi et al., 2016; Gul and Whalen, 2016).

Previous studies have shown that application of oakand hickory-derived biochar, reduced $\mathrm{N}$ leaching in soils treated with organic fertilizers, and that gaseous and leaching loss of soil $\mathrm{N}$ were significantly reduced in Alfisols and Vertisols after the addition of animal manure and eucalyptus biochar. Moreover, modified biochar effectively reduced the risk of $\mathrm{N}$ leaching in the meadow cinnamon soils of northern China (Xu et al., 2016). On the other hand, research has also shown that biochar amendment accelerates the leaching of nitrite from soils (Eykelbosh et al., 2015). Varying results of biochar application may however, be because of differences in the soil and biochar types that were studied.

Red soils are widely distributed in southern China, and experience persistent and strong leaching which leads to low fertility (Liu et al., 2016). This soils generally has a $\mathrm{pH}$ range of 4.0-5.5. Sandy soils consist of coarse soil particles and have a loose texture, making these soils particularly vulnerable to water and fertilizer loss, as well as relatively nutrient-poor (Zhang et al., 2015). Salinized soils are generally impermeable, highly saline, and have little organic matter (Huo et al., 2017), with $\mathrm{pH}$ levels typically exceeding 9 .

The objective of this research was to compare and contrast the effects of biochar amendment on $\mathrm{N}$ dynamics in each of these three soil types.

\section{Materials and Methods}

\subsection{Soil and biochar}

Soil samples were collected from the surface layers $(0-20 \mathrm{~cm})$ of fields with red soil $\left(23^{\circ} 6^{\prime} \mathrm{E}, 114^{\circ} 25^{\prime} \mathrm{N}\right)$ in the district of Huizhou, Guangdong (China); sandy soil (121 $\left.1^{\circ} 53^{\prime} \mathrm{E}, 42^{\circ} 42^{\prime} \mathrm{N}\right)$ in Zhangwu, Liaoning
(China); and coastal solonchak (122 $\left.03^{\prime} \mathrm{E}, 41^{\circ} 22^{\prime} \mathrm{N}\right)$ in Panjin, Liaoning (China). The soils were air-dried and passed through a $2-\mathrm{mm}$ sieve. The basic properties of the soil are presented in Table 1.

Rice hull obtained from Shenyang Agricultural University, China, was selected as the biochar feedstock for this experiment. Biochar (OBC) was produced by pyrolyzing the rice hull biomass at $500{ }^{\circ} \mathrm{C}$ for $30 \mathrm{~min}$ under oxygen-limited conditions. Part of the biochar (WBC) was rinsed with distilled water until all $\mathrm{NH}_{4}^{+}$$\mathrm{N}$ and $\mathrm{NO}_{3}^{-}-\mathrm{N}$ was removed, then allowed to air-dry for a day followed by overnight oven-drying at $80^{\circ} \mathrm{C}$.

\subsection{Preparation of soil columns}

Samples of OBC and WBC were selected to study the effects of biochar on nutrient retention and release in the three soils. Soil columns were made of PVC piping measuring $22 \mathrm{~cm}$ in height and $4.0 \mathrm{~cm}$ in diameter. The bottom of the columns were covered with screen gauze (pore size $61 \mu \mathrm{m}, 240$ mesh) and fitted with PVC end caps, to prevent soil losses. Columns were dry-packed with soil (200 g by dry weight) to which biochar had been added ( $30 \mathrm{~g}$ by weight), with $\mathrm{N}$ concentrations of approximately 85 $\mathrm{kg} \mathrm{ht}^{-1}$; columns containing untreated soil were set as controls.

\subsection{Soil column incubation and leaching}

The columns were incubated at constant room temperature $\left(32{ }^{\circ} \mathrm{C}\right)$ and $80 \%$ relative humidity for the duration of the study. Two hundred $\mathrm{mL}$ of doubledistilled water was poured into the top of each column every $15 \mathrm{~d}$ to simulate leaching, for a total of 27 leaching events. The leachate was collected from each column in $200 \mathrm{~mL}$ polyethylene bottles approximately 12 $\mathrm{h}$ after the start of the leaching event, and all leachate samples were stored at $4{ }^{\circ} \mathrm{C}$ for later use. Soil samples 
were collected after 1, 2, 3, 5, 8, and 13 months of incubation and air-dried for future use.

\subsection{Analysis of leachate and soil}

Samples were filtered sequentially with a $0.45 \mu \mathrm{m}$ filter membrane prior to analysis of $\mathrm{NH}_{4}^{+}-\mathrm{N}^{-}$and $\mathrm{NO}_{3}^{-}-\mathrm{N}$ amounts and volumes in the leachate, which was conducted with an AA3 Continuous Flow Analytical System (SEAL AA3, Germany).

Soil $\mathrm{pH}$ was measured with a calibration-check $\mathrm{pH}$ meter (HANNA HI2221, Italy) based on a soil-to-water ratio of $1: 2.5$. The $\mathrm{NH}_{4}^{+}-\mathrm{N}$ and $\mathrm{NO}_{3}^{-}-\mathrm{N}$ amounts of soils were extracted with $2 \mathrm{M} \mathrm{KCl}$ and determined by AA3 Continuous Flow Analytical System. Total N and total carbon $(\mathrm{C})$ of both the biochar and the three soils were determined using an elemental analyzer (Vario MACRO Cube, Elementar, Germany).

The enzymes included in our analyses consisted of soil dehydrogenase and the three $\mathrm{N}$-cycling enzymes nitrate reductase, nitrite reductase, and hydroxylamine reductase. The potential activities of nitrate reductase were measured by adding $1 \mathrm{~g}$ of the samples $\left(20 \mathrm{mg} \mathrm{CaCO}_{3}\right.$ was added to red soil samples) to $1 \mathrm{ml}$ of $0.8 \mathrm{mmol} \mathrm{L}^{-1}$ 2,4-dinitrophenol solution, which was then mixed with $1 \mathrm{~mL}$ of $0.05 \% \mathrm{KNO}_{3}$ solution, $1 \mathrm{~mL}$ of $1 \%$ glucose solution, and $7 \mathrm{~mL}$ of deionized water. The mixture was then incubated for $24 \mathrm{~h}$ at $30^{\circ} \mathrm{C}$, following which 1 $\mathrm{mL}$ of saturated aluminum potassium alum solution and $4 \mathrm{~mL}$ of chromogenic agent were added. The final mixture was then filtered and analyzed with a colorimeter at a wavelength of $520 \mathrm{~nm}$. Nitrate reductase activity was expressed as milligrams of $\mathrm{NO}_{2}^{-}-\mathrm{N}$ per kilogram per day (i.e., $\mathrm{mg} \mathrm{NO}_{2}-\mathrm{N} \mathrm{kg}^{-1} \mathrm{~d}^{-1}$ ) (Nowak et al., 2002).

Nitrite reductase activity was determined in a manner similar to that used to measure nitrate reductase activity, except that $2 \mathrm{ml}$ of $0.25 \% \mathrm{NaNO}_{2}$ solution was used as the substrate.

Hydroxylamine reductase activity was measured by adding $1 \mathrm{~g}$ of soil $\left(20 \mathrm{mg} \mathrm{CaCO}_{3}\right.$ was added to the red soil samples) to a mixture of $1 \mathrm{~mL}$ of $1 \%$ $\mathrm{NH}_{2} \mathrm{OH} \cdot \mathrm{HCl}, 1 \mathrm{~mL}$ of $1 \%$ glucose solution, and $7 \mathrm{~mL}$ of deionized water. Nitrogen flow removed air in the tube. Following $5 \mathrm{~h}$ of incubation at $30{ }^{\circ} \mathrm{C}, 2 \mathrm{~mL}$ of saturated aluminum potassium alum solution, $1 \mathrm{~mL}$ of buffer solution, $1 \mathrm{~mL}$ of $\mathrm{NH}_{4} \mathrm{Fe}\left(\mathrm{SO}_{4}\right)_{2}$ solution, and $1 \mathrm{~mL}$ of 1,10-phenanthroline monohydrate ethanol solution were then added. Activity was determined with a colorimeter at a wavelength of $510 \mathrm{~nm}$ and expressed as milligrams of $\mathrm{NH}_{2} \mathrm{OH}$ per gram of soil for $5 \mathrm{~h}$ (i.e., $\mathrm{mg} \mathrm{NH}_{2} \mathrm{OH} \mathrm{g}^{-1}$ soil $5 \mathrm{~h}^{-1}$ ). Soil dehydrogenase was determined according to the procedures described by Nowak et al., (2002), with 2,3,5-triphenyltetrazolium chloride used as the substrate.

Table 1. Physicochemical characterization of biochar and soils.

\begin{tabular}{cccccc}
\hline Parameter & $\begin{array}{c}\text { Original } \\
\text { biochar } \\
(\mathrm{OBC})\end{array}$ & $\begin{array}{c}\text { Washed } \\
\text { biochar } \\
(\mathrm{WBC})\end{array}$ & $\begin{array}{c}\text { Red } \\
\text { soil }\end{array}$ & $\begin{array}{c}\text { Sandy } \\
\text { soil }\end{array}$ & $\begin{array}{c}\text { Coastal } \\
\text { solonchak }\end{array}$ \\
\hline $\mathrm{pH}$ & $9.3 \pm 0.2$ & $7.2 \pm 0.2$ & $4.7 \pm 0.3$ & $7.6 \pm 0.2$ & $8.8 \pm 0.2$ \\
$\mathrm{NH}^{+}-\mathrm{N}$ & $56.8 \pm 0.3$ & 0 & $20.3 \pm 0.5$ & $8.4 \pm 0.7$ & $12.9 \pm 0.7$ \\
$\left(\mathrm{mg} \mathrm{kg}^{-1}\right)$ & & & & & \\
$\mathrm{NO}_{3}{ }^{-}-\mathrm{N}$ & $145.6 \pm 0.6$ & 0 & $20.9 \pm 0.6$ & $21.7 \pm 0.5$ & $4.2 \pm 0.4$ \\
$\left(\mathrm{mg} \mathrm{kg}^{-1}\right)$ & & & & & \\
\hline
\end{tabular}

All data are means \pm standard error of the mean $(n=3)$. 


\subsection{Statistical analysis}

Data collected were analyzed via ANOVA using SPSS18.0 software. The t-tests were conducted to compare treatment effects. Least significant difference (LSD) analyses were used to test for differences between means, with significance set to $\mathrm{p}<0.05$ GraphPad Prism 5 was used to create the figures.

\section{Results}

3.1. Effect of biochar on the cumulative volume of leachates

Biochar addition significantly reduced the cumulative volume of leachates by $3.8 \%, 8.6 \%$, and $18.1 \%$ in red, sandy, and coastal solonchak soils, respectively $(\mathrm{P}<0.05)$ (Figure 1).

The cumulative volume of leachates during the first leaching event was significantly lower than volumes at later leaching times, and the cumulative volume of leachates of all amended soils was significantly lower than that of the controls in the different types of soil during the first leaching time $(\mathrm{P}<0.01)$. In addition, WBC significantly reduced the cumulative volume of leachates by $48.6 \%, 53.5 \%$, and $70.7 \%$ compared to the controls in the red, sandy, and coastal solonchak soils, respectively $(\mathrm{P}<0.01)$, whereas reductions as a result of $\mathrm{OBC}$ addition were $41.9 \%, 42.4 \%$, and $68.9 \%$, respectively.

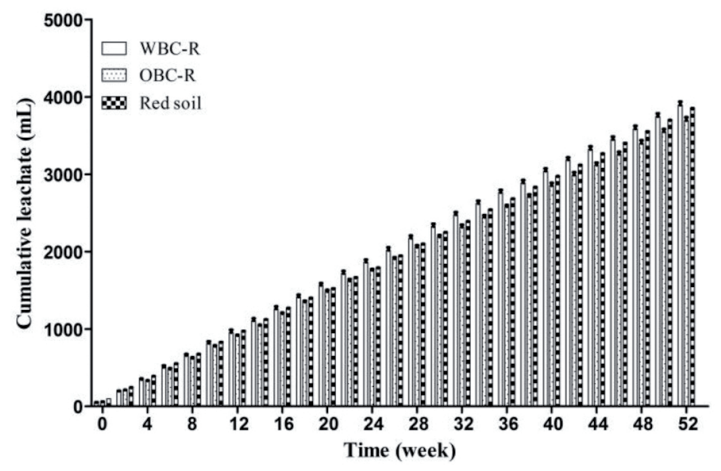

B

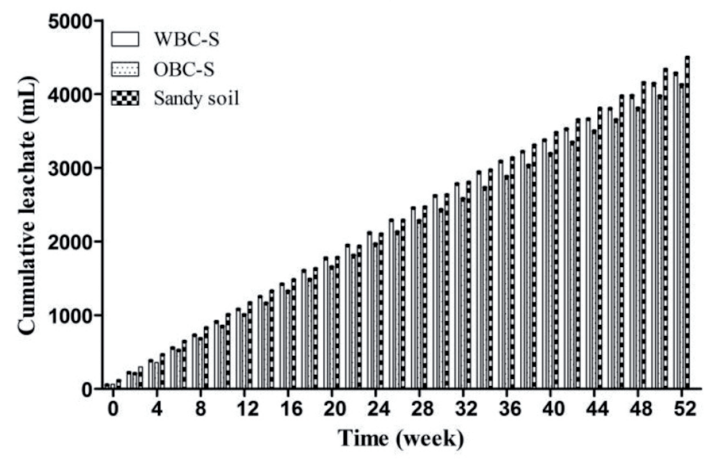

C

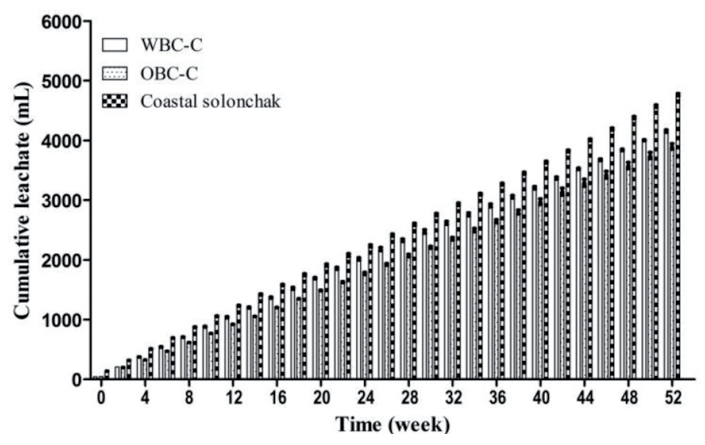

Figure 1. Effect of biochar on the cumulative volume of leachates. (A) Red soil; (B) sandy soil; (C) coastal solonchak. Data represent averages of three replicates; error bars are one standard deviation. 
A

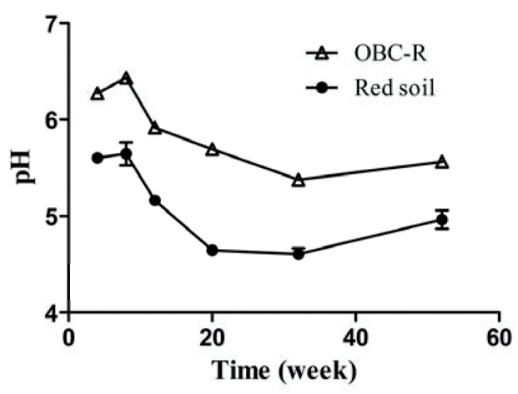

B

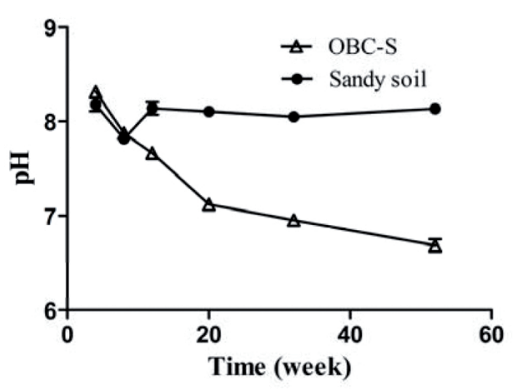

C

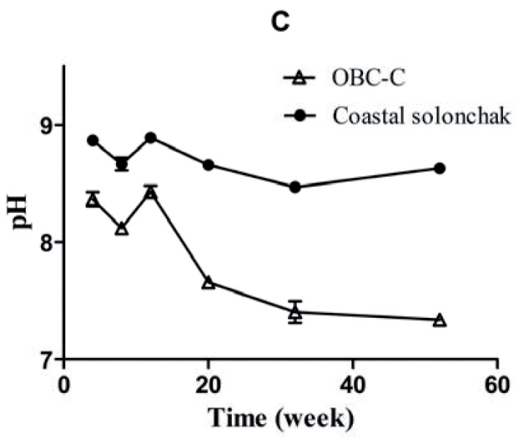

Figure 2. Effect of biochar on soil pH. (A) Red soil; (B) sandy soil; (C) coastal solonchak. Data represent averages of three replicates; error bars are one standard deviation.

\subsection{Effect of biochar on soil $p H$}

Biochar addition affected $\mathrm{pH}$ of the three types of soil in different ways (Figure 2). The $\mathrm{pH}$ of OBC-red (OBC-R) soils was significantly higher than that of controls $(\mathrm{P}<$ 0.05 ), although $\mathrm{pH}$ of both OBC-red and control soils increased (Figure 2A), indicating that biochar addition had a powerful effect on the $\mathrm{pH}$ of red soils; thus, the addition of this type of biochar helped to alleviate the acidity of red soil. In contrast, although biochar addition did not have a statistically significant effect on the $\mathrm{pH}$ of sandy soils $(\mathrm{P}>0.05)$ (Figure 2B), $\mathrm{pH}$ of OBC-sandy (OBC-S) soils was markedly lower than that of controls following biochar addition. The $\mathrm{pH}$ of $\mathrm{OBC}$-coastal solonchak (OBC-C) soils was significantly lower than that of control soils $(\mathrm{P}<0.05)$, indicating that biochar addition greatly reduced the $\mathrm{pH}$ of coastal solonchak soil. Breakthrough curves revealed that although coastal solonchak $\mathrm{pH}$ was stable during all stages, it decreased gradually over time. These results confirmed that biochar could serve as an effective amendment for enhancing or reducing soil $\mathrm{pH}$ levels, depending on the soil type.

\subsection{Effect of biochar on $\mathrm{NH}_{4}-\mathrm{N}$ retention and release in the three types of soil}

The extent of $\mathrm{NH}_{4}^{+}-\mathrm{N}$ leaching from biochar-amended soils varied with soil and biochar type (Figure 3). Biochar addition significantly influenced the cumulative amount of $\mathrm{NH}_{4}^{+}-\mathrm{N}$ leached from red soils (Figure 3A), The cumulative amounts of $\mathrm{NH}_{4}^{+}-\mathrm{N}$ leached from $\mathrm{OBC}-\mathrm{R}$ and WBC-R were markedly lower than red soils $(\mathrm{P}<0.05)$. The cumulative amount of $\mathrm{NH}_{4}^{+}-\mathrm{N}$ leached from OBC-R samples was considerably higher than that leached from WBC-R samples, mainly because WBC had no $\mathrm{NH}_{4}^{+}$$\mathrm{N}$ of its own. Leaching of $\mathrm{NH}_{4}^{+}-\mathrm{N}$ from the sandy and OBC-S soils exhibited a similar trend to that for red soils (Figure 3B), whereas the cumulative amount of $\mathrm{NH}_{4}^{+}-\mathrm{N}$ leached from coastal solonchak amended with biochars exhibited a trend opposite to those observed in red and sandy soils, in which the amounts of $\mathrm{NH}_{4}^{+}$-N increased after biochar addition (Figure $3 \mathrm{c}$ ). This may be because the cumulative amount of $\mathrm{NH}_{4}^{+}-\mathrm{N}$ removal from coastal solonchak was due to surface runoff, whereas removal from WBC-C and OBC-C was the result of leaching. 


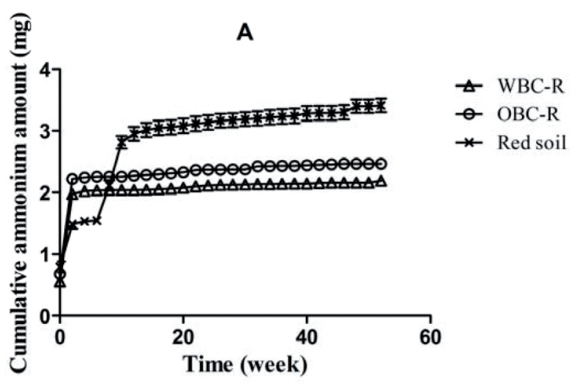

declining sharply to minimal levels after 10 weeks in all biochar-amended samples. Concentrations then rebounded slightly before falling once more, a temporal pattern that was similar to that observed in the controls for all three types of soil. No significant differences were detected in the amounts of $\mathrm{NH}_{4}{ }^{+} \mathrm{N}$ between the biochar-amended soils and the controls after the cessation of leaching.
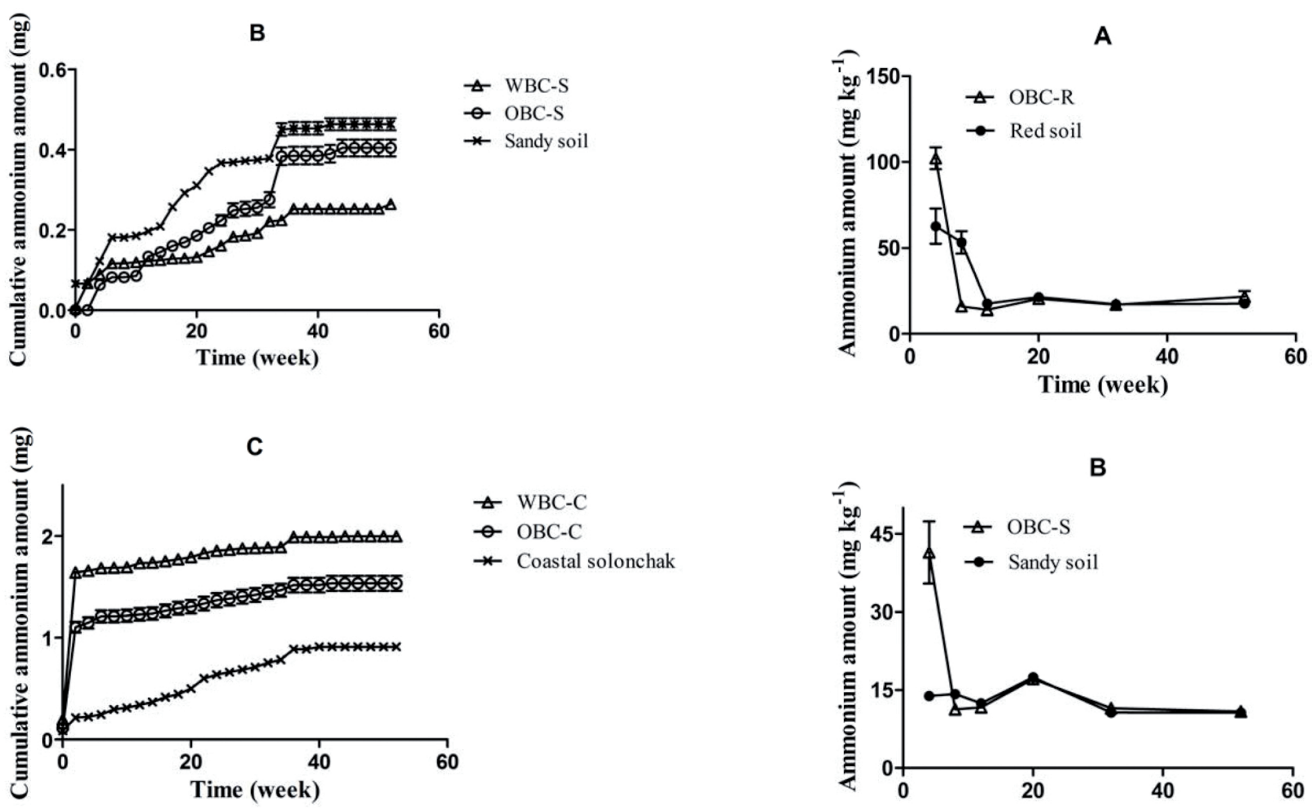

Figure 3. Effect of biochars on $\mathrm{NH}_{4}^{+}-\mathrm{N}$ retention and release in the three types of soil. (A) Red soil; (B) sandy soil; (C) coastal solonchak. Data represent averages of three replicates; error bars are one standard deviation.

\subsection{Effect of biochar on $\mathrm{NH}_{4}^{+}-\mathrm{N}$ content of soil}

Biochar addition had similar effects on the amount of $\mathrm{NH}_{4}^{+}-\mathrm{N}$ across the different types of soil. Concentrations of $\mathrm{NH}_{4}^{+}$-N were significantly affected by the application of biochar during the early period of leaching (Figure 4), attaining a maximal value in the first week, and then
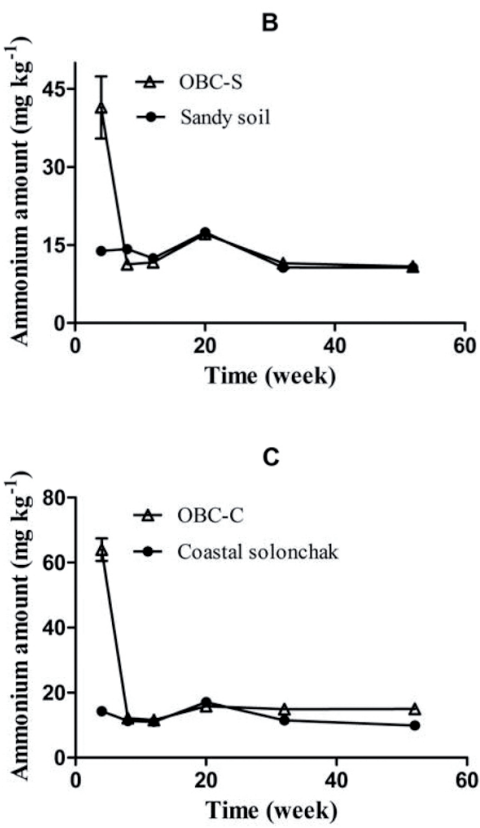

Figure 4. Effect of biochars on the $\mathrm{NH}_{4}^{+}$-N content of soil. (A) Red soil; (B) sandy soil; (C) coastal solonchak. Data represent averages of three replicates; error bars are one standard deviation. 


\subsection{Effect of biochar on $\mathrm{NO}_{3}^{-}-\mathrm{N}$ retention and release} in the three types of soil

Curves reflecting the cumulative leachate losses of $\mathrm{NO}_{3}^{-}-\mathrm{N}$ from soils subjected to the different treatments during the leaching events are shown in Figure 5. Significantly greater amounts of cumulative $\mathrm{NO}_{3}^{-}-\mathrm{N}$ were leached from soils amended with $\mathrm{OBC}$ and WBC than control soils $(\mathrm{P}<0.01)$. Average leachate losses of $\mathrm{NO}_{3}^{-}-\mathrm{N}$ were $84.3 \%$ and $85.8 \%$ higher from soils treated with $\mathrm{WBC}$ and $\mathrm{OBC}$ than from the red soil, $102.1 \%$ and $102.7 \%$ higher than from the sandy soil,
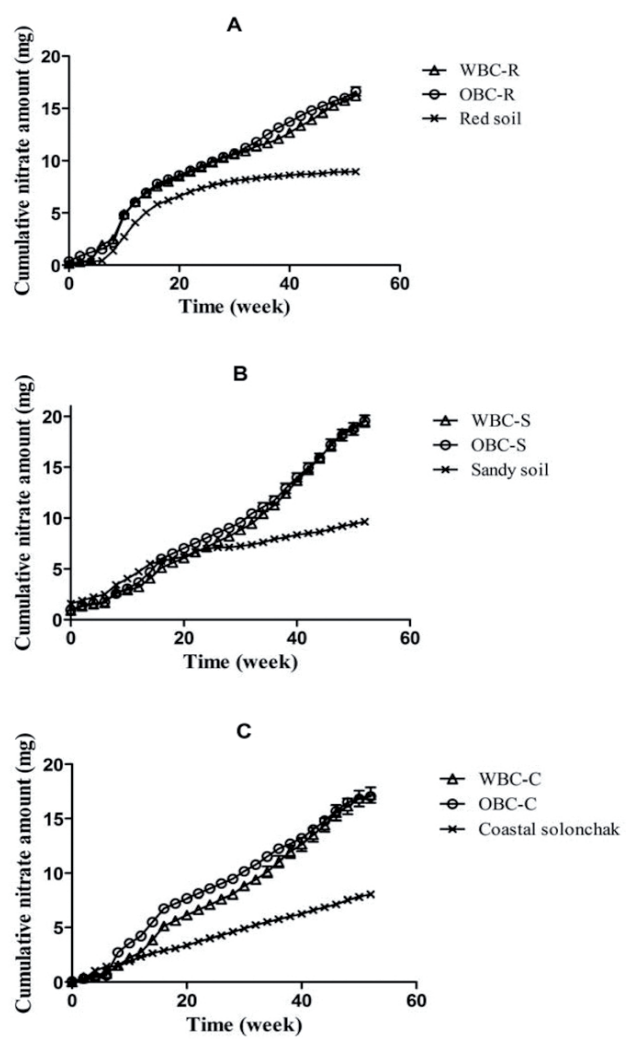

Figure 5. Effect of biochars on $\mathrm{NO}_{3}^{-}-\mathrm{N}$ retention and release in the three types of soil. (A) Red soil; (B) sandy soil; (C) coastal solonchak. Data represent averages of three replicates; error bars are one standard deviation. and $113.7 \%$ and $112.2 \%$ higher than from the coastal solonchak soil. No differences were found in the amount of cumulative $\mathrm{NO}_{3}{ }^{-} \mathrm{N}$ loss between the two kinds of biochar-treated soil; however, cumulative $\mathrm{NO}_{3}^{-}-\mathrm{N}$ loss from $\mathrm{OBC}$-treated soil was slightly higher than from WBC-treated soil, which can be attributed to the $\mathrm{NO}_{3}^{-}-\mathrm{N}$ present in the biochar.

\section{A}

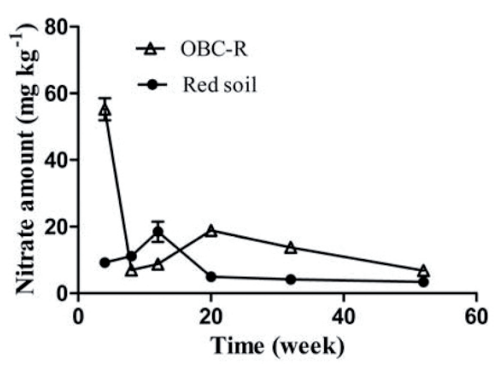

B

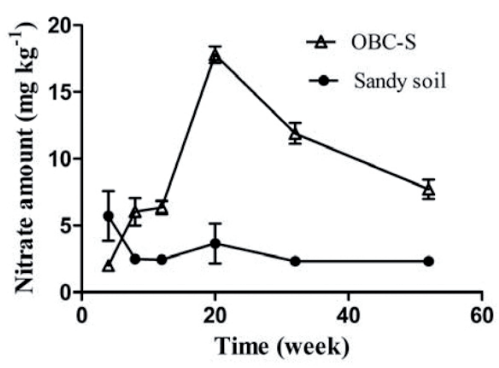

C

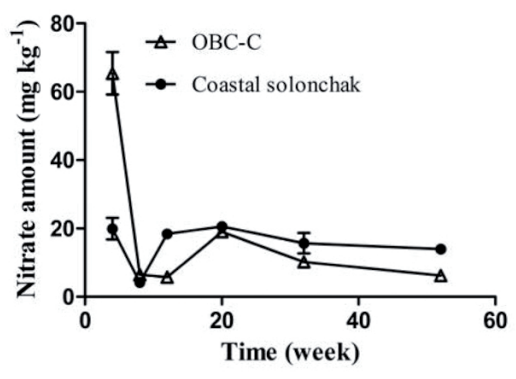

Figure 6. Effect of biochar on the $\mathrm{NO}_{3}^{-}-\mathrm{N}$ content in soil. (A) Red soil; (B) sandy soil; (C) coastal solonchak. Data represent averages of three replicates; error bars are one standard deviation. 


\subsection{Effect of biochar on $\mathrm{NO}_{3}^{-}-\mathrm{N}$ content in soil}

Concentrations of $\mathrm{NO}_{3}^{-}-\mathrm{N}$ in soils subjected to the different treatments at various stages of the experiment are presented in Figure 6. Significant differences were observed between treatments at all stages $(\mathrm{P}<0.05)$. Abundance of $\mathrm{NO}_{3}^{-}-\mathrm{N}$ in the red and coastal solonchak soils were significantly lower than in soils amended with $\mathrm{OBC}$ at the time of the first leaching event $(\mathrm{P}<0.05)$, following which amounts decreased rapidly. In contrast, the amount of $\mathrm{NO}_{3}{ }^{-} \mathrm{N}$ in soils amended with OBC-S initially increased before eventually decreasing. Thus, biochar addition resulted in higher levels of $\mathrm{NO}_{3}^{-}-\mathrm{N}$ in the red and sandy soils over the treatment period, whereas $\mathrm{NO}_{3}{ }^{-}$-N levels fell in coastal solonchak and OBC-C.

3.7. Effect of biochar on the enzymatic activities in the three types of soil

Addition of biochar had different effects on enzymatic activity during leaching periods in the three types of soil (Figure 7). Incubation with biochar for 16 and 26 weeks resulted in the significant increase in the activities of nitrate reductase in the red soil compared with the control $(\mathrm{P}<0.01)$ (Figure 7A-1), and the highest activity occurred at 13 months after biochar treatment compared with that in the control (Figure 7A-1).
The nitrate reductase activity in OBC-S was remarkably lower than in the control at six weeks of incubation ( $\mathrm{P}<0.01)$, and no differences were found between sandy soil and OBC-S in other incubation periods (Figure 7B-1). The nitrate reductase activity in OBC-C was significantly higher than in the controls at 1 month, 3 months, 5 months, and 13 months of incubation $(\mathrm{P}<0.05)$ (Figure $7 \mathrm{C}-3)$. Although no significant differences were found between $\mathrm{OBC}-\mathrm{C}$ and coastal solonchak, the nitrate reductase activity in biochar treatments were higher than in the controls. No significant differences were found in the activities of nitrite reductase and hydroxylamine reductase among treatments (Figure 7B, C). These results indicate that biochar addition could increase nitrate reductase activities, but other soil enzymes involved in nitrogen cycling had no response after biochar addition.

Soil dehydrogenase activities responded in similar ways in red and coastal solonchak soils; activity levels of this enzyme were lower in the biochar-amended soils than in control soils during the early period of incubation, a pattern that was reversed after prolonged biochar addition (Figure 7D-1, D-3). Soil dehydrogenase activities were significantly higher in the biochar-amended sandy soil than in the control soils during all incubation times (Figure 7D-2), suggesting that biochar application had a greater effect on the sandy soil than on the other two types of soils. 


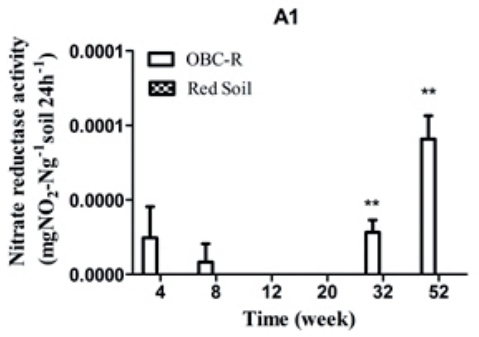

B1

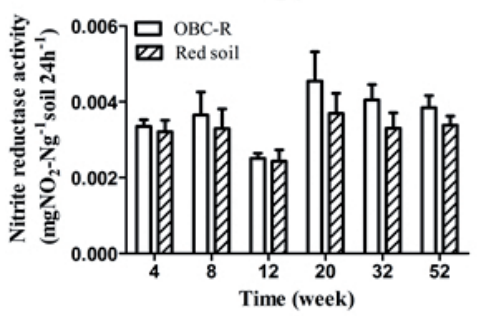

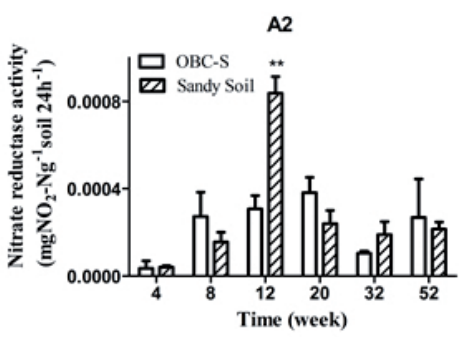

B2

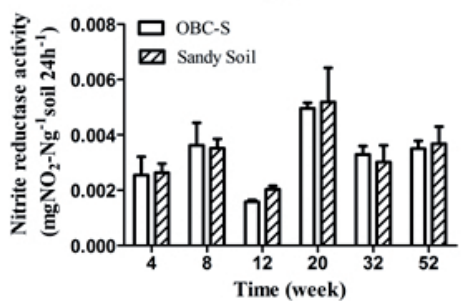

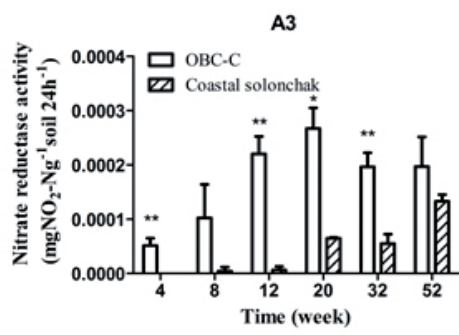

B3

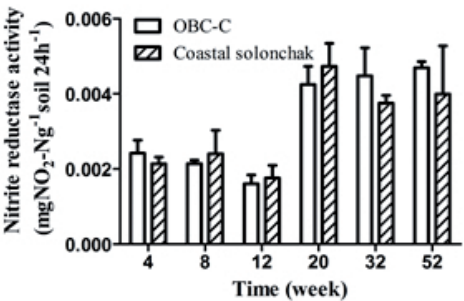

Figure 7. Effect of biochar on enzymatic activities in the three types of soil. (A) Nitrate reductase activity; (B) nitrite reductase activity; (C) hydroxylamine reductase activity; (D) soil dehydrogenase activity; (1) red soil; (2) sandy soil; (3) coastal solonchak. Asterisks and double asterisks indicate a significant difference from the non-amended control at $\mathrm{p}<0.05$ and $\mathrm{p}<0.01$, respectively. Data represent averages of three replicates; error bars are one standard deviation.

\section{Discussion}

$\mathrm{NH}_{4}^{+}-\mathrm{N}$

We found that the effects of biochar addition on $\mathrm{NH}_{4}{ }^{+}-$ $\mathrm{N}$ leaching and $\mathrm{NH}_{4}^{+}-\mathrm{N}$ contents in soils varied markedly depending on the characteristics of the biochar and the type of soil. Washed biochar and original biochar both significantly reduced cumulative $\mathrm{NH}_{4}^{+}-\mathrm{N}$ leaching in red and sandy soils $(\mathrm{P}<0.05)$. Previous studies have shown that biochar improved soil holding capacity for $\mathrm{NH}_{4}^{+}-\mathrm{N}$ by enhancing cation exchange due to the acid functional groups (e.g., hydroxy, carbonyl, and carboxyl) on its surface (Clough et al., 2010; Iqbal et al., 2015). Saleh et al., (2012) also reported that only $0.4 \%$ of total absorbed $\mathrm{NH}_{4}^{+}$was released because of increasingly strong sorption activity via physical entrapment in the pores of biochar. In addition, biochar reduced the risk of $\mathrm{N}$ leaching loss by improving soil water holding capacity (Laird et al., 2010; Zheng et al., 2013), which was confirmed here by the lower cumulative volumes of leachate observed in the biocharamended soils (Figure 1).

Enhancement of water retention in soils treated with biochar can be attributed to changes in several aspects of soil physical structures, including bulk density, porosity, pore size distribution, and soil surface area, which alters permeation rates and flow paths (Major et al., 2012; Zheng et al., 2013; Varela Milla et al., 2013). For instance, flow paths in coastal solonchak soils were observed to switch from runoff to leaching as a result of biochar addition due to the changes in the density of the soil structure 
in the original coastal solonchak soil. Moreover, although no significant differences were detected in the cumulative $\mathrm{NH}_{4}^{+}-\mathrm{N}$ contents of the leachate in soils treated with WBC and those treated with $\mathrm{OBC}$, they were higher in the leachate of soils treated with $\mathrm{OBC}$ than in the leachate of soils treated with WBC. However, $\mathrm{NH}_{4}^{+}-\mathrm{N}$ contents of leachates from red soils amended with $\mathrm{WBC}$ and $\mathrm{OBC}$ were higher during the early leaching stage but subsequently decreased. Biochars evidently adsorbed $\mathrm{NH}_{4}^{+}-\mathrm{N}$, but the effect was negligible; biochar therefore promoted $\mathrm{NH}_{4}^{+}-\mathrm{N}$ leaching more strongly than it enhanced adsorption, implying that most $\mathrm{NH}_{4}^{+}-\mathrm{N}$ was lost through during the early leaching stages but was retained during later leaching periods. In contrast, $\mathrm{NH}_{4}^{+}-\mathrm{N}$ leaching patterns following biochar addition were considerably different in coastal solonchak soils compared to red and sandy soils, mainly due to the change in leaching form, from runoff of coastal solonchak to the leaching of $\mathrm{OBC}-\mathrm{C}$ and $\mathrm{WBC}-\mathrm{C}$, resulting in the acceleration of $\mathrm{NH}_{4}^{+}-\mathrm{N}$ leaching. Thus, our results indicated that biochar addition reduced the amount of $\mathrm{NH}_{4}{ }^{+}-\mathrm{N}$ lost via leaching in red and sandy soils but had the opposite effect in coastal solonchak soils.

Concentrations of $\mathrm{NH}_{4}^{+}-\mathrm{N}$ were highest during the early period of incubation and then sharply decreased in all biochar-treated soils regardless of soil $\mathrm{pH}$. Thus, direct addition of $\mathrm{NH}_{4}^{+}-\mathrm{N}$ deriving from biochar had a strong but short-term effect. The biochar contained alkaline minerals and negative-functional groups (Zheng et al., 2013) but not at levels $(\mathrm{pH}>8)$ that would result in significant ammonia volatilization from the soils (DeLuca et al., 2006). Moreover, concentrations of $\mathrm{NH}_{4}^{+}-\mathrm{N}$ in the sandy and coastal solonchak soils were low; therefore, ammonia volatilization in all three soils should be negligible. No significant differences were detected among all biochar treatments and controls for hydroxylamine reductase activity, which provided further evidence that ammonia volatilization was negligible. Biochar application had a limited effect on soil enzymatic activities in the different types of soil. Such changes in enzymatic activities might be a response to moisture or temperature conditions, soil $\mathrm{pH}$, and nutrient abundance, among other factors (Kotroczó et al., 2014). Bailey et al., (2011) reported that some enzymatic activities increased after $7 \mathrm{~d}$ of biochar application to soil, which may be attributed to stimulation of microbial activity by the biochar. Lehmann et al., (2011) found that the significant impact of biochar on microorganisms was related to the nutrient transformations in soil that resulted from biochar amendment, and that microorganisms were sensitive to changes in the chemical properties of soil, results that were consistent with those of Bailey et al., (2011).

Soil dehydrogenase activities in the three types of soil generally increased with biochar addition compared to controls, with soil dehydrogenase activities significantly higher in biochar-amended sandy soil than in the controls during the entire incubation period (Figure 7D-2). There were no significant differences between biochar treatments and controls in terms of nitrite reductase and hydroxylamine reductase activities over the entire incubation period. Nitrate reductase activity levels increased in the red and coastal solonchak soils as a result of biochar addition during the incubation period (Figure 7A), but not in sandy and OBC-S soils. Nitrite reductase plays an important role in soil denitrification in alkaline soils, but the activity level of this enzyme was low in all treatments. Wang et al., (2015) also reported that soil enzymatic activities related to $\mathrm{N}$ cycling were insufficient to result in substantial changes to the overall concentrations of $\mathrm{NH}_{4}^{+}-\mathrm{N}$ and $\mathrm{NO}_{3}^{-}-\mathrm{N}$. Thus, in our study, the direct addition of biochar appears to be the most important factor for improving $\mathrm{NH}_{4}^{+}-\mathrm{N}$ concentrations in soil.

$\mathrm{NO}_{3}-\mathrm{N}$ 
Many studies that have suggested that biochar addition reduces the loss of $\mathrm{NO}_{3}^{-}-\mathrm{N}$ via leaching or increases soil accumulation were conducted over relatively short incubation periods (days to months) (Novak et al., 2010; Angst et al., 2013; Eykelbosh, 2015; Xu et al., 2016) and thus long-term leaching effects may have been overlooked. As such, analysis of $\mathrm{NO}_{3}^{-}-\mathrm{N}$ leaching or retention should give priority to longterm biochar amendment rather than over short-term scales. In this study, we found that biochar addition enhanced the retention of $\mathrm{NO}_{3}^{-}-\mathrm{N}$ in the early phase of the experiment, but $\mathrm{NO}_{3}^{-}-\mathrm{N}$ lost via leaching increased at later stages, as shown by the $\mathrm{NO}_{3}^{-}-\mathrm{N}$ curves depicted in Figure 5. This change in the rate of immobilization over time was most likely due to adsorption of $\mathrm{NO}_{3}{ }^{-} \mathrm{N}$ by the biochar material. Kameyama et al., (2012), for example, reported that adsorption of $\mathrm{NO}_{3}^{-}-\mathrm{N}$ was mainly due to base functional groups and not to physical sorption, and thus, adsorption of $\mathrm{NO}_{3}^{-}-\mathrm{N}$ by biochar is weak. Sorption of $\mathrm{NO}_{3}^{-}-\mathrm{N}$ on the biochar surface may be due to electrostatic interactions (outer-sphere complexation) and, to a lesser extent, ionic exchange (Jassal et al., 2015). At the same time, the negative functional groups present on the surface of biochar may evolve at high $\mathrm{pH}$ and generates $\mathrm{OH}^{-}$that competes with $\mathrm{NO}_{3}^{-}-\mathrm{N}$, limiting the sorption of $\mathrm{NO}_{3}^{-}-\mathrm{N}$ (Chintala et al., 2013). However, biochar promoted $\mathrm{NO}_{3}^{-}-\mathrm{N}$ retention and accelerated its release in biochar-amended soils regardless of whether the biochar was washed or type of soil, results that are consistent with those of previous studies (Eykelbosh, 2015; Major et al., 2012). Furthermore, no significant differences were found in the rates of $\mathrm{NO}_{3}^{-}-\mathrm{N}$ leaching between the WBC and $\mathrm{OBC}$ treatments, and WBC treatments were significantly higher than controls. This may be because WBC and OBC increased soil porosity, and thus, promoted $\mathrm{NO}_{3}^{-}-\mathrm{N}$ leaching, and because of the stimulatory effects that biochar has on the soil $\mathrm{N}$ pool that organic $\mathrm{N}$ mineralized to nitrate. Overall, we found that biochar addition accelerated $\mathrm{NO}_{3}^{-}-\mathrm{N}$ leaching, and that the $\mathrm{NO}_{3}^{-}-\mathrm{N}$ of biochar did not play an important role in this effect.

Biochar addition resulted in alterations in the amounts of $\mathrm{NO}_{3}^{-}-\mathrm{N}$ in these three soils at both the middle and final leaching stages (Figure 5), results that may be due to the final $\mathrm{NH}_{4}^{+}-\mathrm{N}$ contents of biochar-amended soils being lower than at the start of the treatments. Whereas final amounts of $\mathrm{NO}_{3}{ }^{-} \mathrm{N}$ were higher (Figure 6), suggesting that the presence of biochar accelerated nitrification rates during which $\mathrm{NH}_{4}^{+}-\mathrm{N}$ was transformed to $\mathrm{NO}_{3}^{-}-\mathrm{N}$ (Kanthle et al., 2016). Furthermore, the effect of transient $\mathrm{NO}_{3}^{-}-\mathrm{N}$ addition by biochar faded over prolonged leaching time in red and coastal solonchak soils, but not in sandy soils. Thus, biochar amendment had different effects on $\mathrm{NO}_{3}{ }^{-} \mathrm{N}$ transformation in the different types of soil, and the effect of the addition of $\mathrm{NO}_{3}^{-}-\mathrm{N}$ deriving from biochar was significant in sandy soils, possibly because soil dehydrogenase activities were significantly higher in OBC-S than in controls, and because biochar addition enhanced both microbial activities and $\mathrm{NO}_{3}{ }^{-} \mathrm{N}$ concentrations. Thus, although biochar promoted $\mathrm{NO}_{3}{ }^{-}-\mathrm{N}$ leaching, its application also led to increases in $\mathrm{NO}_{3}{ }^{-}-\mathrm{N}$ concentrations in the three soils, and particularly in sandy soils, suggesting that the effects of biochar on nitrate dynamics in these types of soils were generally positive.

\section{Conclusion}

Here, we examined the loss and retention of $\mathrm{NH}_{4}{ }^{+} \mathrm{N}$ and $\mathrm{NO}_{3}^{-}-\mathrm{N}$ due to leaching and changes in enzymatic activities in response to biochar addition in soils after $390 \mathrm{~d}$ of incubation. Leaching of $\mathrm{NH}_{4}^{+}-\mathrm{N}$ was reduced in red and sandy soils after biochar addition, but was elevated in coastal solonchak soils. However, biochar amendment significantly accelerated the release of $\mathrm{NO}_{3}^{-}-\mathrm{N}$ in later leaching events. No differences were 
found between soils treated with $\mathrm{OBC}$ and $\mathrm{WBC}$, indicating that the amount of $\mathrm{NO}_{3}^{-}-\mathrm{N}$ present in the biochar had little influence on the loss of $\mathrm{NO}_{3}^{-}-\mathrm{N}$. Of the three $\mathrm{N}$-related soil enzymes examined, only nitrate reductase activities were observed to increase after biochar addition, although microbial activities were also enhanced. In summary, biochar addition affected the retention and release of $\mathrm{NH}_{4}{ }^{+}-\mathrm{N}$ and $\mathrm{NO}_{3}{ }^{-}-\mathrm{N}$ in different ways depending on the soil type and the level of microbial activity.

\section{Acknowledgements}

This research was financially supported by the Special Fund for Agro-scientific Research in the Public Interest of China (No. 201303095), the Program for Excellent Talents of Education Department of Liaoning Province, the Liaoning Province Science and Technology Program (No. 2014215019), Chinese Academy of Engineering Consulting Project (No. 2015-XY-25).

\section{References}

Abujabhah, I.S., Bound, S.A., Doyle, R., Bowman, J.P. 2015. Effects of biochar and compost amendments on soil physico-chemical properties and the total community within a temperate agricultural soil. Appl. Soil Ecol. 98, 243-253.

Awasthi, M.K., Wang, Q., Ren., X.N., Zhao, J.C., Huang, H., Awasthi, S.K., Lahori, A.H., Li, R.H., Zhang, Z.Q. 2016. Role of biochar amendment in mitigation of nitrogen loss and greenhouse gas emission during sewage sludge composting. Bioresource Technol. 219, 270-280.

Bailey, V.L., Fansler, S.J., Smith, J.L., Bolton, H. 2011. Reconciling apparent variability in effects of biochar amendment on soil enzyme activities by assay optimization. Soil Biol. Biochem. 43(2), 296-301.
Angst, T.E., Patterson, C.J., Reay, D.S., Anderson, P., Peshkur, T.A., Sohi, S.P. 2013. Biochar diminishes nitrous oxide and nitrate leaching from diverse nutrient sources. J. Environ. Qual. 42(3), 672-682.

Chintala, R., Mollinedo, J., Schumacher, T.E., Papiernik, S.K., Malo, D.D., Clay, D.E., Kumar S., Gulbrandson D.W. 2013. Nitrate sorption and desorption in biochars from fast pyrolysis. Microporous \& Mesoporous Materials. 179(10), 250-257.

Clough, T.J., Condron, L.M., Pignatello, J., Katz, B.G. 2010. Biochar and the nitrogen cycle: introduction. Journal of Environmental Quality. 39(4), 1218-23.

DeLuca, T.H, MacKenzie, M.D, Gundale, M.J, Holben, W.E. 2006. Wildfire-produced charcoal directly influences nitrogen cycling in ponderosa pine forests. Soil Sci. Soc. Am. J. 70(2), 448-453.

Eykelbosh, A.J., Johnson, M.S., Couto, E.G. 2015. Biochar decreases dissolved organic carbon but not nitrate leaching in relation to vinasse application in a brazilian sugarcane soil. J. Environ. Manag. 149, 9-16.

Freddo, A., Chao, C., Reid, B.J. 2012. Environmental contextualization of potential toxic elements and polycyclic aromatic hydrocarbons in biochar. Environmental Pollution. 171(4), 18-24.

Gul, S., Whalen, J.K. 2016. Biochemical cycling of nitrogen and phosphorus in biochar-amended soils. Soil Biol. Biochem. 103, 1-15.

Huo, L., Pang, H.C., Zhao, Y.G., Wang, J., Lu, C., Li, Y.Y. 2017. Buried straw layer plus plastic mulching improves soil organic carbon fractions in an arid saline soil from northwest china. Soil Till. Res. 165, 286-293.

Iqbal, H., Garcia-Perez, M., Flury, M. 2015. Effect of biochar on leaching of organic carbon, nitrogen, and phosphorus from compost in bioretention systems. Science of the Total Environment. 522, 37-45. 
Jassal, R.S., Johnson, M.S., Molodovskaya, M., Black, T.A., Jollymore, A., Sveinson, K. 2015. Nitrogen enrichment potential of biochar in relation to pyrolysis temperature and feedstock quality. J Environ. Manage. 152, 140-144.

Kameyama, K., Miyamoto, T., Shiono, T., Shinogi, Y. 2012. Influence of sugarcane bagasse-derived biochar application on nitrate leaching in calcaric dark red soil. J. Environ. Qual. 41(4), 1131-1137.

Kanthle, A.K., Lenka, N.K., Lenka, S., Tedia, K. 2016. Biochar impact on nitrate leaching as influenced by native soil organic carbon in an inceptisol of central India. Soil Till. Res. 157, 65-72.

Kotroczó, Z., Veres, Z., Fekete, I., Krakomperger, Z., Tóth, J.A., Lajtha, K., Tóthmérész B. 2014. Soil enzyme activity in response to long-term organic matter manipulation. Soil Biol. Biochem. 70(2), 237-243.

Laird, D., Fleming, P., Wang, B., Horton, R., Karlen, D. 2010. Biochar impact on nutrient leaching from a midwestern agricultural soil. Geoderma. 158(3), 436-442.

Lehmann, J., Rillig, M.C., Thies, J., Masiello, C.A., Hockaday, W.C., Crowley, D. 2011. Biochar effects on soil biota - a review. Soil Biol. Biochem. 43(9), 1812-1836.

Liu, Y.J., Yang, J., Hu, J.M., Tang, C.J., Zheng, H.J. 2016. Characteristics of the surface-subsurface flow generation and sediment yield to the rainfall regime and land-cover by long-term in-situ, observation in the red soil region, southern china. J. Hydrol. 539, 457-467.

Major, J., Rondon, M., Molina, D., Riha, S.J., Lehmann, J. 2012. Nutrient leaching in a colombian savanna oxisol amended with biochar. J. Environ. Qual. 41(4), 1076-86.
Novak, J.M., Busscher, W.J., Watts, D.W., Laird, D.A., Ahmedna, M.A., Niandou, M.A.S. 2010. Short-term $\mathrm{CO}_{2}$ mineralization after additions of biochar and switchgrass to a typic kandiudult. Geoderma. 154, 281-288.

Nowak, J., Kaklewski, K., Klódka, D. 2002. Influence of various concentrations of selenic acid (iv) on the activity of soil enzymes. Sci. Total Environ. 291(1-3), 105-110.

Varela, O., Rivera, E.B., Huang, W.J., Chien, C., Wang, Y.M. 2013. Agronomic properties and characterization of rice husk and wood biochars and their effect on the growth of water spinach in a field test. J. Soil Sci. and Plant Nutr. 13(2), 251-266.

Wang, C., Anderson, C., Suárez-Abelenda, M., Wang, T., Camps-Arbestain, M., Ahmad, R., Herath, H.M.S.K. 2015. The chemical composition of native organic matter influences the reponse of baterial community to input of biochar and fresh plant material. Plant and Soil. 395, 87-104.

Wang, X., Song, D., Liang, G., Zhang, Q., Ai, C., Zhou, W. 2015. Maize biochar addition rate influences soil enzyme activity and microbial community composition in a fluvo-aquic soil. Appl. Soil Ecol. 96, 265-272.

Xu, N., Tan, G.C., Wang, H.Y., Gai, X.P. 2016. Effect of biochar additions to soil on nitrogen leaching, microbial biomass and bacterial community structure. Eur. J. Soil Biol. 74, 1-8.

Zhang, J., Chen, Q., You, C.F. 2015. Numerical simulation of mass and heat transfer between biochar and sandy soil. Int. J. Heat Mass Tran. 91, 119-126.

Zheng, H., Wang, Z.Y., Deng, X., Zhao, J., Luo, Y., Novak, J., Herbert, H., Xing, B.S. 2013. Characteristics and nutrient values of biochars produced from giant reed at different temperatures. Bioresource Technol. 130(2), 463-471. 